Pak. j. sci. ind. res. Ser. B: biol. sci. 2018 61B(2) 103-111

\title{
Comparative Toxicity of Spinetoram and Nitenpyram against Earthworm and their Effects on Protein Contents and Cholinesterase Activity
}

\author{
Altaf Hussain ${ }^{a *}$, Muhammad Farhanullah Khan ${ }^{\mathrm{a}}$, Omer Mukhtar ${ }^{\mathrm{b}}$, Muhammad Faheem ${ }^{\mathrm{a}}$ \\ and Umeed Ali ${ }^{\mathrm{b}}$ \\ ${ }^{a}$ Department of Zoology, University of Karachi, Karachi-75270, Pakistan \\ ${ }^{b}$ Food \& Marine Resources Research Centre, PCSIR Laboratories Complex, Karachi-75280, Pakistan
}

(received December 19, 2016; revised July 29, 2017; accepted August 1, 2018)

\begin{abstract}
The earthworms' numbers and biodiversities are considered as an indicator of soil nature and fertility. Earthworms are very important soil organisms that aid in the decomposition of plant litter. In recent era earthworm obtain more attention in agriculture practices, so that in the present work to determined the comparative effects of nitenpyram and spinetoram on total amount of protein and cholinesterase activity of Pheretima posthuma Kinberg (Order: Haplotaxida and Family: Megaseolecide ) earthworm. Total protein contents were found to be decreased significantly in the peristomium, clitellum, and abdomen regions under treatments of nitenpyram and spinetoram. Cholinesterase activities were inhibited in the peristomium, clitellum and abdomen under the exposures of nitenpyram and spinetoram, at the intervals of 30,60 and 90 seconds in P. posthuma. Conclusively it is safe to say that spinetoram is better than neonicotinoids for the earthworms, therefore could be switched from neonicotiniods as an IPM component.
\end{abstract}

Keywords: enzyme, bio-pesticide, neonicotinoid, earthworm

\section{Introduction}

Nitenpyram is being used as a novel insecticide in the class of neonicotinoid pesticides (Tomlin, 1997). It has also been recognized as an effective systemic insecticide to the flea in feeding tests on cattle (Tinembart et al., 1999) and frequently used on foliar fields, especially, on horticultural fields, applied in attracted formulations for household uses against ants and cockroaches, also used in granular formulations to the management of amenity and meadow grasslands against ground dwelling insect pests. It could be applied in irrigation water to defend persistent of various crops and introduced into the timber to fighting the termites (Oliver et al., 2010). These insecticides are fetched $1 / 3$ of the total pesticide traded (Simon-Delso et al., 2015). They could be applied through irrigating water to field crops and introduced into timber as termiticide (Oliver et al., 2010). Therefore, they could get way to the inner soil layers. Studies have proved that neonicotinoids could get way in the course of underground water, hence, damaging the agro soil atmosphere (Bacey, 2000). It not only effect on farming soil but also adversely affect the soil dwelling organisms thus, develop ultimate unfavorable effects on agroecosystems. On the other hand, earthworms have been observed plentiful in the most of the soil ecosystems

*Author for correspondence; E-mail: profaltaf@hotmail.com and considered as reformer in the ground ecosystems, as they vigorously regulate the physical, chemical and natural of the polluted soils (Bottinelli et al., 2010; Binet et al., 1998; Jones et al., 1997). They have significant effect on richness and porosity of soil (Wang et al., 2004). Bustos-Oberg-n and Goicochea (2002) have pointed out that owing to extensive use of agro pesticides the danger of soil contamination has provoked a growing concern the world over.

Spinetoram is used as biopesticide. Biopesticides are used with an understanding that they are safer than other insecticides. Thus spinetoram is supposed to exerts low lethal impacts and least environmentally threaten product (DAS, 2008). The spinetoram showed highly successful results against variety of insects in various crop fields and pose reduced risk to natural enemies reported by Srivastava et al. (2008); El Kady et al. (2007); Mahmoud and Osman, (2007); Reita et al. (2003); Williams et al. (2003); Kirst et al. (1992). Spinetoram showed its impacts either by stomach and contact poison and degraded rapidly in the atmosphere as reported by Cisneros (2002) and directly exerted its impacts on receptors of $\gamma$-aminobutyric acid and nicotinic acetylecholine (Shimokawatoko et al., 2012). The pesticides are known to exert adverse effects on soil beneficial fauna e.g. the earthworms (Pfiffiner et al., 
2014) as the earthworm has significant effect on richness and porosity of soil (Wang et al., 2004). Lawrence and London (1997) reported that the earthworms make the soil $\mathrm{pH}$ neutral as well. In view of importance of earthworms, growing trend of using neonicotinoids, presently effects of nitenpyram were evaluated against earthworm in comparison with spinetoram as an alternate pest controlling compound.

\section{Materials and Methods}

Identification of earthworm. The procured earthworms were already identified, however, for further confirmation; identification was made after purposed and designed key by Stephenson (1923) for the earthworm species identification. Body of Pheretima posthuma Kinberg is approximately $13-15 \mathrm{~cm}$ in length, having a brownish bright colour. The whole body consists of segments 100-120. The anterior of the body has peristomium, fewer segments are made a thick band called as clitellum and remaining of body after clitellum is called as abdomen. The genital pore of female found on ventral side of $14^{\text {th }}$ segment of the body, whereas genital pore of male on ventral side of $18^{\text {th }}$ segment of the body just behind to clitellum. Copulatory papillae present on the venereal side of segments no $17^{\text {th }}$ and $19^{\text {th }}$ of the body. In the last segment, there is a vertical slit-like anus (Kotpal et al., 1987).

Rearing and culturing of earthworm. The procured earthworm was kept in the laboratory at around 20-25 ${ }^{\circ} \mathrm{C}$ with a humidity level above $80 \%$, for the process of rearing. Rearing was carried out in wooden made rearing chambers on the similar soil from where they were initially collected. The soil was consisting of suitable organic materials for earthworm's development. A suitable amount of water as needed by earthworms was added in order to maintain moisture level. The earthworms were kept well protected in rearing chamber with muslin cloth from all predators, contamination and attrition. In the said experiment all the earthworms having age 20-40 days of maturity were used.

Spinetoram was purchased from an authorized pesticide dealer with the trade mark of Delegate $25 \% \mathrm{w} / \mathrm{w}$ and nitenpyram was procured with the trade mark of knockout $25 \% \mathrm{w} / \mathrm{w}$. It is a product of Sygenta Corporation (both pesticides were procured from its authorized dealers in the Karachi city of Pakistan). Additionally, dilutions of these pesticides have been made and either pesticide for testing in sterile soil.
$\mathrm{LD}_{50}$ of the spinetoram and nitenpyram were measured after based on Finney (1971). Standard deviation, Standard error and mortality rang at $95 \%$ confirmed limits have been measured as well.

Statistical analysis. Charle's Formula. To make various concentrations of under test compounds following formula was used for calculations.

$$
\mathrm{C}_{1} \mathrm{~V}_{1}=\mathrm{C}_{2} \mathrm{~V}_{2}
$$

Where:

$$
\begin{aligned}
& \mathrm{C}_{1}=\text { original concentration of solute; } \\
& \mathrm{C}_{2}=\text { final concentration of solvent; } \\
& \mathrm{V}_{1}=\text { initial volume of solute; } \\
& \mathrm{V}_{2}=\text { final volume of solvent; }
\end{aligned}
$$

Abbot's Formula. Obtained readings have been subjected to Abbot's formula that is as following:

Abbot's formula $=\%$ Kill- Kill in Control * 100*(100 - Control mortality $)^{-1}$

Standard deviation (S.D.). The S.D. in the mortality of all compounds taking place at different concentrations has been measured by following formula:

$$
\text { S.D. }=\left[\Sigma(\mathrm{x}-\overline{\mathrm{X}})^{2} \cdot(\mathrm{n}-1)^{-1}\right]^{0.5}
$$

Where:

$\overline{\mathbf{X}}=$ Average of variable $\mathrm{x}$;

$\mathrm{X}=$ Notation for variations of variable $\mathrm{x}$;

S. D. = Standard deviation;

$\mathrm{n} \quad=$ Total number of observations.

\section{Standard error (S.E.).}

$$
\text { S.E. }=\left[\mathrm{SD}^{2} . \mathrm{n}^{-1}\right]^{0.5}
$$

Where:
$\mathrm{n} \quad=$ Total number of observations;
S. E. $=$ Standard error;
S. D. $=$ Standard deviation .

Range. Range at significance value of $95 \%$ confidence limit has been measured by using following formula:

$$
\text { Range }=X \pm \text { S.E. } x 1.96
$$

Estimation of total contents of protein. To find out the effect of spinetoram and nitenpyram on the protein contents, ten mature earthworms were treated with 
respective $\mathrm{LD}_{50}$ 's for $48 \mathrm{~h}$. After $48 \mathrm{~h}$ the treated active worms were drawn out and relevant parts dissected out and homogenisation was prepared in a test tube by "Disperser" homogeniser for $30 \mathrm{~min}$ at a speed of $80 \%$ of the device in $3 \mathrm{~mL}$ de-ionized water. Subsequently, homogenised samples were centrifuged for $20 \mathrm{~min}$ at a speed of $15000 \mathrm{rpm}$.

A Sigma Italia test kit no. 10031 was used to estimate the total contents of protein (based on Biuret method). Five test tubes were used as control, blank, standard, spinetoram, nitenpyram and one milli litter of Biuret reagent was taken in all tubes. After that 20 micro liter of standard was taken in tubes and 20 liters of compounds (spinetoram and nitenpyram and control) were taken in particular tubes. After mixing almost half an hour, it was placed at $25^{\circ} \mathrm{C}$. The absorbance of sample and standard were calculated at $546 \mathrm{~nm}$ wavelength against the reagent blank.

\section{Chemicals}

Biuret Reagent; Standard protein $60 \mathrm{~g} / \mathrm{L}$; NaOH 0.75 $\mathrm{mmol} / \mathrm{L}$; Na-K-tartarate $20 \mathrm{mmol} / \mathrm{L}$; KI $6 \mathrm{mmol} / \mathrm{L}$; $\mathrm{Cu}_{2} \mathrm{SO}_{4} 7 \mathrm{mmol} / \mathrm{L}$

Determination of cholinesterase activity. For the determination of cholinesterase activity a kit from Boehringer Mannheim Gm Bh, No. 124125 was used. The method depends upon hydrolysis of acetylcholine by the action of cholinesterase (Knedel and Boettger, 1967).

Currently, the S-butyrylthiochloline iodide has been used as substrate. Whereas 2-nitrobenzoate (5, 5dithiobis) has been used as indicator that is decreased by thiocholine released to form the yellow colored 5mercapto-2-2 nitrobenzoate. The activity of cholinesterase is attained from the rate of colour pattern that is calculated photometrically.

\section{Chemicals}

(i) $0.134 \mathrm{M}$ of phosphate buffer ( $\mathrm{pH} 7.2)$ was made by mixing seven parts $(\mathrm{v} / \mathrm{v})$ of disodium hydrogen phosphate $(47.8 \mathrm{~g} / \mathrm{L})$ and three parts of potassium dihydrogen phosphte $(18.156 \mathrm{~g} / \mathrm{L})$.

(ii) $0.04 \mathrm{M}$ of acetylcholine was made by dissolving acetylcholine chloride $(0.7266 \mathrm{~g})$ in $100 \mathrm{ml}$ of $0.001 \mathrm{M}$ of acetate buffer ( $\mathrm{pH} 4.5$ ).

(iii) Acetate buffer was made by mixing $28 \mathrm{~mL}$ of sodium acetate trihydrate $(0.2 \mathrm{M})$ with $22 \mathrm{~mL}$ of acetic acid $(0.2 \mathrm{M}) .1$ volume of reagent two has been diluted with nine volumes of reagent one used newly. (iv) Freshly prepared solution of hydroxylamine hydrochloride (2M) was taken.

(v) In bidistilled water sodium hydroxide (3.5M) was prepared.

(vi) Newly prepared solution of alkaline hydroxy lamine through mixing the same volume of reagents ' $d$ ' and ' $\mathrm{e}$ '.

(vii) Solution of HCL was made by mixing 1 volume of $\mathrm{HCl}$ (conc.) with two volumes of bidistilled water. (viii) Ferric chloride $(0.37 \mathrm{M})$ solution was made in $10 \% \mathrm{HCl}$.

Each regent was stored at $3^{\circ} \mathrm{C}$.

\section{Results and Discussion}

In the carried out studies, the total amount of protein in different three regions of imago Pheretima posthuma earthworms i.e. peristomium, clitellum and abdomen have been observed by applying the treatments of nitenpyram and spinetoram after the period of $48 \mathrm{~h}$.

Under the treatments of nitenpyram the total amount of protein were estimated as $38.8 \pm 0.46,48.1 \pm 0.18$ and $39.0 \pm 0.46 \mathrm{mg} / \mathrm{mL}$ to respective regions as peristomium, clitellum and abdomen in the earthworms Pheretima posthuma (Table 1). In the case of untreated earthworms the total protein amount was $70.2 \pm 0.46,82.0 \pm 0.25$ and $65.5 \pm 0.35 \mathrm{mg} / \mathrm{mL}$ in the regions i.e., peristomium, clitellum and abdomen (Table 1).

Under the exposures of spinetoram total protein content found to be $30.8 \pm 0.35,34.0 \pm 0.22$ and $44.5 \pm 0.28 \mathrm{mg} / \mathrm{mL}$ to respective regions as peristomium, clitellum and abdomen in the earthworms Pheretima posthuma (Table 2). While, in the case of untreated earthworms the total protein amount to be $72.0 \pm 0.25,80.5 \pm 0.35$ and $63.4 \pm 0.31 \mathrm{mg} / \mathrm{mL}$ in the respective regions i.e. peristomium, clitellum and abdomen (Table 2).

Faheem et al. (2012) evaluated the total amount of protein in the earthworm Pheretima posthuma under exposure for the period of $48 \mathrm{~h}$ of cypermethrin and neem fruit extract. Faheem et al. (2010) postulated that decrease in the total amount of protein owing to the harsh segregation take place in proteins of nucleic plasm as compared to the proteins content of cytoplasmic and also considered key role as bio-indicators of whole metabolic activities of all body cells, to play major role in the various function of all cells of organisms. Above results are in line with the present findings of decline 
in protein contents under exposure of pesticides e.g., nitenpyram and spinetoram.

These proteins could be used for the energy production in the body of organism however, under the exposure to the pesticides resulted reduction in metabolic functions as reported by Granett and Leeling (1971). The toxicity of pesticides on protein contents was found in the hemolymph and proteins nature of stem borer of rice under the treatments of different insecticides by Saleem and Shakoori (1987). Chang et al. (1974) reported the toxic effect after the treatments of malathion and permethrin and on amount of protein in Tribolium castaneum (Order: Coleoptera and family: Cerambycidae). In current studies, the protein content in the earthworm some changes found in the region of abdomen under the treatment of spinetoram as compared to nitenpyram effects are in conformities (Faheem et al.,
2012; 2010; Saleem and Shakoori, 1987; Chang et al., 1974).

The amount of protein in different organisms has been decreased after the treatment of insecticide as reported by Tabassum and Naqvi (2001); Mohamed and Hafez (2000). Javaid (1989) investigated the effects under the treatments of neem formulations against the bollworm larvae and the amount of protein was reduced as investigated by Gujar and Mehrota (1985). Saleem and Shakoori (1985) observed the reduction in protein content after the effect of permethrin and deltamethrin. The amount of protein has been reduced in the immature Drosophila melanogaster (Order: Diptera and family: Drosophilidae) after the Duter ${ }^{\mathrm{TM}}$ exposure. Other researchers also reported the impact of various insecticides on enzymes and proteins of animals ( Naqvi et al., 1995; Yasmin et al., 1994; Rizvi et al., 1990;

Table 1. Impact of nitenpyram on total protein in peristomium, clitellum and abdomen regions of Pheretima posthuma earthworm.

\begin{tabular}{|c|c|c|c|c|c|c|}
\hline \multirow{3}{*}{$\begin{array}{l}\text { Nitenpyram } \\
\text { Peristomium region }\end{array}$} & \multicolumn{2}{|c|}{$\begin{array}{l}\text { Mean of protein } \\
\text { content }(\mathrm{mg} / \mathrm{mL})\end{array}$} & \multirow{2}{*}{$\begin{array}{l}\text { S.D. } \\
0.65\end{array}$} & \multirow{2}{*}{$\begin{array}{l}\text { S.E. } \\
0.46\end{array}$} & \multirow{2}{*}{$\begin{array}{l}\text { Variance } \\
0.42\end{array}$} & \multirow{2}{*}{$\begin{array}{l}\text { Range at } 95 \% \\
\text { confidence } \\
\text { limit S.Ex } 1.96 \\
37.90-39.76\end{array}$} \\
\hline & Treated & 38.86 & & & & \\
\hline & $\begin{array}{l}\text { Untreated } \\
\text { (Control) }\end{array}$ & 70.2 & 0.52 & 0.37 & 0.28 & $69.40-70.90$ \\
\hline \multirow[t]{2}{*}{ Clitellum region } & Treated & 48.1 & 0.26 & 0.18 & 0.07 & $47.70-48.40$ \\
\hline & $\begin{array}{l}\text { Untreated } \\
\text { (Control) }\end{array}$ & 82.0 & 0.80 & 0.25 & 0.65 & $80.80-83.00$ \\
\hline \multirow[t]{2}{*}{ Abdomen region } & Treated & 39.0 & 0.65 & 0.46 & 0.43 & $38.00-39.90$ \\
\hline & $\begin{array}{l}\text { Untreated } \\
\text { (Control) }\end{array}$ & 65.5 & 0.50 & 0.35 & 0.25 & $64.80-66.10$ \\
\hline
\end{tabular}

Table 2. Impact of spinetoram on total protein in peristomium, clitellum and abdomen regions of Pheretima posthuma earthworm.

\begin{tabular}{|c|c|c|c|c|c|c|}
\hline \multirow{2}{*}{$\begin{array}{l}\text { Spinetoram } \\
\text { Peristomium }\end{array}$} & \multicolumn{2}{|c|}{$\begin{array}{l}\text { Mean of protein } \\
\text { content }(\mathrm{mg} / \mathrm{mL})\end{array}$} & \multirow{2}{*}{$\begin{array}{l}\text { S.D. } \\
0.26\end{array}$} & \multirow{2}{*}{$\begin{array}{l}\text { S.E. } \\
0.18\end{array}$} & \multirow{2}{*}{$\begin{array}{l}\text { Variance } \\
\text { S.Ex1.96 } \\
0.07\end{array}$} & \multirow{2}{*}{$\begin{array}{l}\text { Range at } 95 \% \\
\text { confidence limit }\end{array}$} \\
\hline & Treated & 30.6 & & & & \\
\hline Region & $\begin{array}{l}\text { Untreated } \\
\text { (Control) }\end{array}$ & 72.0 & 0.36 & 0.25 & 0.15 & $71.50-72.40$ \\
\hline \multirow[t]{2}{*}{ Clitellum region } & Treated & 34.0 & 0.32 & 0.22 & 0.25 & $33.50-34.40$ \\
\hline & $\begin{array}{l}\text { Untreated } \\
\text { (Control) }\end{array}$ & 80.5 & 0.50 & 0.35 & 0.28 & $79.00-81.10$ \\
\hline \multirow[t]{2}{*}{ Abdomen region } & Treated & 44.5 & 0.40 & 0.28 & 0.16 & $43.90-45.00$ \\
\hline & $\begin{array}{l}\text { Untreated } \\
\text { (Control) }\end{array}$ & 63.4 & 0.45 & 0.31 & 0.20 & $62.80-45.00$ \\
\hline
\end{tabular}


Bradford, 1976). The reducing impact on protein revealed that the protein may be used for the production of energy in the organisms under the pesticide effect was identified to cause reduction of metabolic reserves as reported by Orr and Doner (1982). In the current investigation earthworm protein content was found less reduced in various regions under post-treatment of spinetoram as compared to nitenpyram treatments. During the current study, the protein amount has been found to be decreased in three parts of the adult earthworm under the exposure of spinetoram and nitenpyram. The decrease of total protein content agrees to the postulations of Tabassum and Naqvi (2001); Mohamed and Hafez (2000); Saleem and Shakoori (1985); Orr and Doner (1982).

Acetylcholinesterase (AChE) is responsible for of neurotransmitter and targeted by various pesticides (Ferrari et al., 2004; Smulders et al., 2003). Thus, AChE is used to detect insecticides toxicity (Sanchez-Hernandez and Moreno-Sanchez, 2002). The decreasing trend of cholinesterase in the earthworms provides the caution concerning injurious impacts of pesticides (Booth and O'Halloran, 2001). The earthworm has significant effect on richness and porosity of soil (Wang et al., 2004). Lawrence and London (1997) reported that the earthworms make the soil $\mathrm{pH}$ neutral as well. BustosOberg-n and Goicochea (2002) have pointed out that owing to extensive use of agro pesticides, the danger of soil contamination has provoked a growing alarm the worldwide. In the present case of work, $\mathrm{ChE}$ inhibition in the P. posthuma under the treatments of nitenpyram to be $86.00 \%, 89.55 \%$ and $87.60 \%$ in the peristomium region, (Table 1), $57.11 \%, 19.42 \%$ and $0.41 \%$ in clitellum (Table 2) and $90.00 \%, 73.96 \%$ and $68.84 \%$ in abdomen at the respective period of time as 30, 60 and 90 seconds (Table 3). In the treatments of spinetoram ChE inhibition observed to be $81.33 \%$, $87.22 \%$ and $95.11 \%$ in peristomium (Table 3 ), $51.62 \%$,

Table 3. Effect of spinetoram and nitenpyram treatment on $\mathrm{ChE}$ activity in peristomium region of earthworm (Pheretima posthuma).

\begin{tabular}{|c|c|c|c|c|c|c|}
\hline \multirow[b]{2}{*}{ Pesticides } & \multicolumn{6}{|c|}{ Parameters } \\
\hline & $\begin{array}{l}\text { Time } \\
\text { (in second) }\end{array}$ & $\begin{array}{l}\text { Mean } \\
(\mathrm{U} / \mathrm{I}), \mathrm{S} . \mathrm{D}( \pm)\end{array}$ & Variance & $\begin{array}{l}\text { Range at } 95 \% \\
\text { confidence limit }\end{array}$ & $\begin{array}{l}\text { Inhibition } \\
\%\end{array}$ & $\begin{array}{l}\text { Enhancement } \\
\%\end{array}$ \\
\hline \multirow[t]{3}{*}{ Nitenpyram } & 30 & $210.7 \pm 0.36$ & 0.13 & $210.2-211.1$ & 86.00 & - \\
\hline & 60 & $180.6 \pm 0.36$ & 0.13 & $180.2-181.1$ & 89.55 & - \\
\hline & 90 & $231.1 \pm 0.79$ & 0.63 & $230.0-232.2$ & 87.60 & - \\
\hline \multirow[t]{3}{*}{ Spinetoram } & 30 & $280.9 \pm 2.00$ & 4.00 & $279.4-283.6$ & 81.33 & - \\
\hline & 60 & $220.8 \pm 1.04$ & 1.08 & 219.3-222.2 & 87.22 & - \\
\hline & 90 & $91.0 \pm 0.95$ & 0.90 & $89.0-92.3$ & 95.11 & - \\
\hline \multirow[t]{3}{*}{ Control } & 30 & $1505.3 \pm 0.57$ & 0.33 & $1504.2-506.0$ & 00 & 00 \\
\hline & 60 & $1728.8 \pm 0.80$ & 0.65 & $1727.6-729.9$ & 00 & 00 \\
\hline & 90 & $1864.6 \pm 2.02$ & 4.10 & $1861.7-867.4$ & 00 & 00 \\
\hline
\end{tabular}

Table 4. Effect of spinetoram and nitenpyram treatment on ChE activity in clitellum region of earthworm (Pheretima posthuma).

\begin{tabular}{lllllll}
\hline \hline \multirow{2}{*}{ Pesticides } & \multicolumn{7}{c}{ Parameters } \\
\cline { 2 - 7 } & $\begin{array}{l}\text { Time } \\
\text { (in second) }\end{array}$ & $\begin{array}{l}\text { Mean } \\
(\mathrm{U} / \mathrm{I}), \mathrm{S} . \mathrm{D}( \pm)\end{array}$ & & $\begin{array}{l}\text { Variance } \\
\text { confidence } \\
\text { limit }\end{array}$ & $\begin{array}{l}\text { Inhibition } \\
\%\end{array}$ & $\begin{array}{l}\text { Enhancement } \\
\%\end{array}$ \\
\hline Nitenpyram & 30 & $182.5 \pm 2.83$ & 8.05 & $178.5-86.4$ & 57.11 & - \\
& 60 & $307.3 \pm 1.52$ & 2.33 & $305.1-309.4$ & 19.42 & - \\
Spinetoram & 90 & $290.5 \pm 0.5$ & 0.25 & $289.8-291.1$ & 00.41 & - \\
& 30 & $205.9 \pm 1.00$ & 1.00 & $204.5-207.2$ & 51.62 & - \\
& 60 & $271.5 \pm 1.45$ & 2.11 & $269.5-273.4$ & 28.81 & - \\
Control & 90 & $224.9 \pm 0.85$ & 0.73 & $223.7-226.0$ & 22.90 & - \\
& 30 & $425.6 \pm 0.55$ & 0.30 & $424.8-426.3$ & 00 & 00 \\
& 60 & $381.4 \pm 1.36$ & 1.85 & $379.5-383.2$ & 00 & 00 \\
\hline \hline
\end{tabular}


Table 5. Effect of spinetoram and nitenpyram treatment on ChE activity in abdomen region of earthworm (Pheretima posthuma).

\begin{tabular}{lllllll}
\hline \hline \multirow{2}{*}{ Pesticides } & \multicolumn{7}{c}{ Parameters } \\
\cline { 2 - 7 } & $\begin{array}{l}\text { Time } \\
\text { (in second) }\end{array}$ & $\begin{array}{l}\text { Mean } \\
(\mathrm{U} / \mathrm{I}), \mathrm{S} . \mathrm{D}( \pm)\end{array}$ & $\begin{array}{l}\text { Vari- } \\
\text { ance }\end{array}$ & $\begin{array}{l}\text { Range at } 95 \% \\
\text { confidence limit }\end{array}$ & $\begin{array}{l}\text { Inhibition } \\
\%\end{array}$ & $\begin{array}{l}\text { Enhancement } \\
\%\end{array}$ \\
\hline Nitenpyram & 30 & $160.9 \pm 1.01$ & 1.03 & $159.5-162.2$ & 90.00 & - \\
& 60 & $361.8 \pm 1.60$ & 2.85 & $359.5-364.0$ & 73.96 & - \\
Spinetoram & 90 & $275.3 \pm 1.52$ & 2.33 & $273.1-277.4$ & 68.84 & - \\
& 30 & $566.3 \pm 1.52$ & 2.33 & $564.1-568.2$ & 64.89 & - \\
\multirow{3}{*}{ Control } & 60 & $357.2 \pm 1.05$ & 1.12 & $355.7-358.6$ & 74.29 & - \\
& 90 & $196.5 \pm 0.5$ & 0.25 & $195.8-197.1$ & 77.76 & - \\
& 30 & $1613.0 \pm 2.00$ & 4.0 & $1610.2-1615.7$ & 00 & 00 \\
& 60 & $1389.8 \pm 0.76$ & 0.58 & $1388.7-1390.8$ & 00 & 00 \\
\hline \hline
\end{tabular}

$28.81 \%$ and $22.90 \%$ in clitellum (Table 4 ) and $64.89 \%$, $74.29 \%$ and $77.76 \%$ abdomen region at the respective period of time as 30, 60 and 90 seconds (Table 5). Present results are in accordance to Shimokawatoko, et al. (2012). They also found that spinetoram directly influences the effects on receptors of nicotinic acetylecholine. Mineau (1993) studied that activity of cholinesterase in wild birds has been decreased after the treatment of carbamate and organophosphate. Shakoori et al. (1994) reported that the cholinesterase inhibition in larvae of Tribolium castaneum (Herbst.) after the treatment of Sumicidin super. Gard \& Hooper (1995) reported the carbamate and organophosphorus as potential acetylcholinesterase inhibitors at nerve synapses. The cholinesterase activities in control of 22 days old adult of daphnids stated expressed per protein content were found as $84.28 \pm 4.84 \mathrm{1} / \mathrm{mol} / \mathrm{min} / \mathrm{mg}$ proteins, $87.26 \pm 6.67 \mathrm{nmol} / \mathrm{min} / \mathrm{mg}$ protein and $0.61 \pm 0.043$ $\mathrm{nmol} / \mathrm{min} / \mathrm{mg}$ protein (Barata et al., 2005; Diamantino et al., 2000; Guilhermino et al.1996). Kristoff et al. (2006) reported the assessment of sample recoveries in the earthworm Lumbricus variegatus, under exposure of azinphos-methyl, inhibition of $\mathrm{ChE}$ observed to be 90\%. Under treatment of chlorpyrifos the $\mathrm{ChE}$ activities found up to $40 \%$ inhibition (Aamodt et al., 2007). In the carried out work, cholinesterase activity was mostly found inhibited under exposure of nitenpyram and spinetoram. In the present study, cholinesterase inhibition activities were observed in the three regions of earthworm as in the peristomium region approximately equal, but in the region of clitellum found a little variation at intervals of 30,60 sec of time and at the interval of $90 \mathrm{sec}$ least inhibition found at post treatments of nitenpyram as compared to under treatments of spinetoram and in the region of abdomen low inhibition found under the treatment of spinetoram as compared under the treatments of nitenpyram. The previous reports showed that the nitenpyram being as (neonicotinoid) is toxic as compared to spinetoram (bio-pesticide). The difference may be due to immediate neurotoxic effect of pesticides that kill the organism by directly inhibiting neuromuscular enzyme that is accordance with above cited researchers in same paragraph.

\section{Conclusion}

Conclusively it is safe to say that spinetoram is better than neonicotinoids for the earthworms, therefore could be switched from neonicotiniods as an IPM component.

\section{References}

Aamodt, S., Konestabo, H.S., Sverdrup, L.E., Gudbrandsen, M., Reinecke, S. A., Reinecke, A. J., Stenersen, J. 2007. Recovery of cholinesterase activity in the earthworm Eisenia fetida Savigny following exposure to chlorpyrifos. Environment Toxicological Chemistry, 26: 1963-1967.

Bacey, J. 2000. "Environmental Fate of Imidacloprid." Environmental Monitoring \& Pest Management Branch, Department of Pesticide Regulation. California. www.cdpr.ca.gov/docs/empm/pubs/ fatememo/imid.pdf. Accessed January 2004.

Barata, C., Varo, I., Navarro, J.C., Arun, S., Porte, C. 2005. Antioxidant enzyme activities and lipid peroxidation in the freshwater Cladoceran Daphnia magna exposed to redox cycling compounds. Comparative Biochemistry and Physiology, 140: 175-186. 
Binet, F., Fayolle, L., Pussard, M., Crawford, J. J., Traina, S. J. Tuovinen, O. H. 1998. Significance of earthworms in stimulating soil microbial activity. Biology Fertility of Soils, 27: 79-84.

Booth, L.H., O'Halloran, K. 2001. A comparison of biomarker responses in the earthworm (Aporrectodea caliginosa) to the organophosphorous insecticides. Diazinon and Chlorpyrifos. Environmental Toxicology and Chemistry, 20: 2494-2502.

Bottinelli, N., Henry-des-Tureaux, T., Hallaire, V., Mathieu, J., Benard, Y., Du Tran, T., Jouquet, P. 2010. Earthworms accelerate soil porosity turnover under watering conditions. Geoderma, 156: 43-47.

Bradford, M.N. 1976. A rapid and sensitive method for the quantitation of microorganisms of protein utilizing the principle of protein dye binding. Annual Biochemistry, 72: 248-254.

Bustos-Oberg-n, E., Goicochea, R.I. 2002. Pesticide soil contamination mainly affects earthworm male reproductive parameters. Asian Journal of Andrology, 4: 195-199.

Chang, S.C., Borkoveo, A.B., Braun, B.H. 1974. Chemosterilant activity of antineoplastic agents. Trans. NewYork Academy of Science, II. 36: 101107.

Cisneros, J., Goulson, D., Derwent, L.C., Penagos, D. I., Hernández, O., Williams, T. 2002. Toxic effects of spinosad on predatory insects. Biological Control, 23: 156-163.

Diamantino, T.C, Guilhermino, L., Almeida, E., Soares, A.M.V.M. 2000. Toxicity of sodium molybdate and sodium dichromate to Daphnia magna Straus evaluated in acute, chronic and acetylcholinesterase inhibition tests. Ecotoxicology Environment Safety, 45: 253-259.

DAS, 2008. Spinetoram. Dow Agro Sciences Technical Bulletin, 1-6.

El-Kady, G. A., El-Sharabasy, H.M., Mahmoud, M.F., Bahgat, I.M. 2007. Toxicity of two potential bioinsecticides against moveable stages of Tetranychus urticae Koch. Journal of Applied Science Research, 3: 1315-1319.

Faheem, M., Khan, M.F. 2010.Toxicity of imidacloprid (Nicotinoid) against earthworm, Pheretima posthuma with reference to its effects on protein. Journal of Basic Applied Science, 6: 55-62.

Faheem, M. 2012. Toxicological studies of neem fruit extract and cypermethrin (pyrethroid) on total protein activity in peristomium, clitellum and abdomen region of earthworm Pheretima posthuma populations of agricultural and non-agricultural ecological zones, (Published in P.hD Thesis). Depatment of Zoology, University of Karachi, Pakistan.

Ferrari, A., Anguiano,O.L., Venturino, A., Pechen, de D'Angelo, A.M. 2004. Different susceptibility of two aquatic vertebrates (Oncorhynchus mykiss and Bufo arenarum) to azynphos methyl and carbaryl. Comparative Biochemistry and Physiology, 139: 239-243.

Finney, D.J. 1971. Probit Analysis, pp.333, Cambridge, Cambridge University Press, UK.

Gard, N.W., Hooper, M.J. 1995. An assessment of potential hazards of pesticides and environmental contaminations, In: Ecology and Management of Neotropical Migratory Birds. pp. 294-307, Oxford University Press, New York, USA.

Granett, J. Leeling, N.C. 1971. Trehalose and glycogen depletion during DDT poisoning of American cockroach Periplaneta americana Ann. Entomological Society of America, 64: 784-789.

Guilhermino, L., Lopes, M.C., Carvalho, A.P., Soares, A.M.V.M. 1996. Acetylcholinesterase activity in juveniles of Daphnia magna Straus. Bulletin of Environmental Contamination and Toxicology, 57: 979-985.

Gujar, G. T., Mehrota, K. N. 1985. Effect of neem oil on consumption, digestion and utilization of maize by desert locust Schistocerca gregaria Forskel. National Academy of Science Letter, 8: 363-365.

Inglesfield, C. 1984. The toxicity of the pyrethroid insecticides cypermethrin and WL-85871 to the earthworm. Bulletin of Environmental Contamination and Toxicology, 33: 568-570.

Javaid, M. A. 1989. Biochemical Investigations on the Effect of Azadirachtin on Development of Heliothis armigera (Hub.), M. Phil. Thesis, Quaid-e-Azam University, Islamabad.

Jones, C.G., Lawton, J.H., Shachak, M. 1997. Positive and negative effects of organisms as physical ecosystem engineers. Ecology, 78: 1946-1957.

Kirst, H.A., Michel, K.H., Mynderse, J.S., Chio, E.H., Yao, R.C., Nakatsukasa, W.M., Oech, D., Occlowitz, J.L., Paschal, J.W., Deeter, J.B.,Thompson, G.D. 1992. Discovery, isolation, and structure elucidation of a family of structurally unique fermentationderived tetracyclic macrolides, In: Baker, D. R., Fenyes, J.G. and Steffans, J.J. (eds) Synth. Chem. Agrochem. pp. 214-225, $3^{\text {rd }}$ edition American Chemical Society, Washangton, DC, USA.

Knedel, M., Boetteger, R. 1967. Kinetic method for 
determination of pseudocholinesterase (acylcholine acylhydrolase) activity. Klinische Wochenschr, 45: 325-327.

Kotpal, R.L., Agarwal, S.K., Khetarpal, R.P. 1987. Modern Text Book of Zoology: Invertebrates. pp. 379-380, Meerut, Rastogi Publishers, India.

Kristoff, G., Guerrero, N.V., de D'Angelo, A.M.P. Cochon, A.C. 2006. Inhibition of cholinesterase activity by azinphos-methyl in two freshwater invertebrates: Biomphalaria glabrata and Lumbriculus variegates. Toxicology, 222: 185-194.

Lawrence, F., London, J.R. 1997. The role of earthworms in healthy soils. Venaura Farm Producer of Naturally Grown Vegetables, 21: 40-44.

Mahmoud, M.F., Osman, M.A.M. 2007. Relative toxicity of some bio-rational insecticides to second instar larvae and adults of onion thrips (Thrips tabaci Lindeman) and their predator Orius albidipennis under laboratory and field conditions. Journal of Plant Protection Research, 47: 391-400.

Mineau, P. 1993. The hazard of carbofuran to birds and other vertebrate wildlife. Technical Report Series No.177, Canadian Wildlife Service, Canada.

Mohamed, M.I., Hafez, S.E. 2000. Biological and biochemical effects of the nonvolatile plant oil (Jojoba) against Culex pipiens (Diptera: Culicidae). Journal of Egyptian-German Society of Zoology, 13: $65-78$.

Naqvi, S.N.H., Temuri, K.H., Nurulain, S.M., Ahmed, I., Larson, R.O. 1995. Toxicity and effect of neem fractions (RB-9, RB-b and Margosan-O) on phosphatases and protein pattern of Culex fatigans (K. U. strain). Pakistan Journal of Pharmacology, 12: 49-52.

Oliver, J.B., Fare, D.C., Youssef, N., Scholl, S.S., Reding, M.E., Ranger, C.M., Moyseenko, J.J., Halcomb, M. A. 2010. Evaluation of a single application of neonicotinoid and multi-application contact insecticides for flatheaded borer management in field grown red maple cultivars. Journal of Environmental Horticulture, 28: 135-149.

Orr, G.L., Doner, R.G.H. 1982. Effect of lindane (Thexachlorocyclohexane) on carbohydrate and lipid reserve in the American cockroach, Periplaneta americana L. pesticides. Biochemistry and Physiology, 17: 89-95.

Pfiffner, L., Peigne, J., Lyon, F., Cooper, P. 2014. Research Institution of Organic Agriculture, FiBL, Switzerland, www. fibl. org.

Reita, S.R., Yearby, E.L., Funderburk, J.E., Stavisky,
J., Momol, M.T., Olson, S. M. 2003. Integrated management tactics for Frankliniella thrips (Thysanoptera: Thripidae) in field-grown pepper. Journal of Economic Entomology, 96: 1201-1214.

Rizvi, S.W.A., Ahmad, I., Zaidi, R.H., Naqvi. S.N.H. 1990. Toxicity, abnormalities and effect on protein pattern by methoprene (ZR-515) on $4^{\text {th }}$ immature stages of red cotton stainer, Dysdercus koenigii (Fabr.). (Hemiptera; Pyrrhocoridae). Pakistan Journal of Phannacology, 8: 43-51.

Saleem, M.A., Shakoori, A.R. 1987. Permethrin and malathion induced macromolecular abnormalities in adults of Tribolium castaneum (Herbst), Arch. Insect Biochemistry and Physiology, 5: 45-57.

Saleem, M.A., Shakoori, A.R. 1985. Effects of permethrin and deltamethrin on some biochemical components of Tribolium castaneum larvae. Pakistan Journal of Zoology, 17: 321-328.

Sanchez-Hernandez, J.C, Moreno-Sanchez, B. 2002. Lizard cholinesterases as biomarkers of pesticide exposure: Enzymological characterization. Environmental Toxicological Chemistry, 21: 2319-2325.

Shakoori, A.R., Agha, S., Saleem, M.A., Ali, S.S. 1994. Biochemical abnormalities produced by sub lethal doses of a synthetic pyrethroid. Sumiciding super on the $6^{\text {th }}$ instar larvae of red flour beetle Tribolium castenum. Pakistan Journal of Entomology Karachi, 9: 5-20.

Shimokawatoko,Y., Sato, N., Tanaka, H., Yamaguchi, T. 2012. Ecotoxicological risk asessment of pesticides in terrestrial ecosystem. Sumitomo Chemical Corporation Limited, Health \& Crop Sciences Research Laboratory, Environmental Health Science Laboratory, This paper is translated from R\&D Report, "SUMITOMO KAGAKU", vol. 2012.

Simon-Delso, N., Amaral-Rogers, V., Belzunces, L.P., Bonmatin, J.M., Chagnon, M., Downs, C., Furlan, L., Gibbons, D.W., Giorio, C., Girolami, V., Goulson, D., Kreutzweiser, D. P., Krupke, C., Liess, M., Long, E., Mc Field, M., Mineau, P., Mitchell, E. A. D., Morrissey, C. A., Noome, D. A., Pisa, L., Settele, J., Stark, J. D., Tapparo, A., Van Dyck, H., Van Praagh, J., Van der Sluijs, J. P., Whitehorn, P. R., W iemers, M. 2015. Systemic insecticides (neonicotinoids and fipronil): trends, uses, mode of action and metabolites. Environmental Science and Pollution Research, 22: 05-34.

Smulders, C. J. G. M., Bueters, T. J. H., Van-Kleef, R. G.D.M., Vijverberg, H.P. M. 2003. Selective effects 
of carbamate pesticides on rat neuronal nicotinic acethylcholine receptors and rat brain acetylcholinesterase. Toxicology and Applied Pharmacology, 193: 139-146.

Srivastava, M., Bosco, L., Funderburk, J., Olson, S., Weiss, A. 2008. Spinetoram is compatible with the key natural enemy of Frankliniella species thrips in pepper. Online, Plant Health Progress, doi: 10.1094/PHP-2008-0118-02 RS.

Stephenson, J. 1923. Oligochaeta Fauna. Fauna of British India Series (London). pp.309-310.

Tabassum, R., Naqvi, S.N.H. 2001. Effect of Dimilin (IGR), NC and NFC (neem extract) on nucleic acid and protein contents of Callosobruchus analis (F). Proceedings of Pakistan Congress of Zoology, 21: 299-303.

Tinembart, O., Moyses, E.W. and Humert-Droze, E. 1999. Flea related irritation in cats and dogs treated with nitenpyram, $17^{\text {th }}$ International Conference of the World Association for the Advancement of Veterinary Parasitology, Copenhagen, August 15 to 19,1999 . Abstracts 3.03 .

Tomlin, C.D.S. 1997. The Pesticide Manual, $11^{\text {th }}$ edition, Farnham British Crop Protection Council, 880 pp.

Wang, X., Li, H.X., Ru, F., Wang, D.D. 2004. Effects of earthworms on nitrogen leaching in wheat field agro-ecosystem. Acta Pedologica Sinica, 41: $987-$ 990 (in Chinese).

Williams, T., Valle, J., Vinuela, E. 2003. Is the naturally derived insecticide Spinosad ${ }^{\circledR}$ compatible with insect natural enemies? Biocontrol Science Technology, 13: 459-475.

Yasmin, N., Naqvi, S.N.H., Khan, M.F., Munir, A. Tariq, R.M. 1994. Role of neem product (Biosol) and its impact on cholinesterase and protein contents in larvae of Papilio demoleus L. in comparison with cypermethrin. Indian Journal of Experimental Zoology, 13: 541-544. 